\title{
Social Incivilities and Perception of Safety: A Qualitative Comparison between Commuters and Residents
}

\author{
Ismail Onat* and Nusret M Sahin \\ Criminology Department, University of Scranton, USA \\ Indiana University South Bend, USA
}

Submission: August 15, 2017; Published: August 24, 2017

*Corresponding author: Ismail Onat, Sociology, Criminal Justice and Criminology Department, University of Scranton, O’Hara Hall, 800 Linden Street, Scranton, PA 18510, USA, Email: ismail.onat@scrantn.edu

\begin{abstract}
This study aims to explore the extent to which social incivilities influence perception of safety in the same environment between on-siteliving vs. commuting respondents to the area when taking also gender into consideration. It examines the link between perceived safety and environmental cues while considering that familiarity with the area, independent of gender difference, can mitigate in this relationship. The research draws on in-depth interviews with twenty-eight students of a university campus in an urban city. Homeless people, street vendors, beggars, and people congregating at street corner were the recurring themes across interviews. The results of the analysis suggest that the commuter group correlates the importune begging and congregating on streets with safety, without a gender difference among respondents. In addition, female respondents more frequently reported homeless people as a problem, without a residential difference among the female students. Social incivilities specific to a campus should be identified to manage public behavior, and to modify the perceived safety.
\end{abstract}

Keywords: Campus safety; Homeless; Street vendor; Beggar; Group congregation

\section{Introduction}

An environment with its social and physical features plays a key role in affecting how safe the occupants perceive a place. As a unique environment, the college campus has garnered a specific attention in the literature, and numerous studies have addresses the feeling of safety on university campuses [1-9]. For the most part, the studies on safety perception among college students focused on gender difference. However, the familiarity with and the time spent on a campus also matter to how safe the students perceive a campus. Besides, few studies have examined which social incivilities on campuses specifically are gendered although safety perception of college campuses has a large body of research.

The current research assumes the time spent on campus may be a mitigating factor in the relationship between perception of safety and the gender of students. In addition, fear-provoking social cues in the settings may have differential impacts on resident and commuter students of the same campus, regardless of gender. This study tests this assumption with student interviews in an open college campus of the Rutgers University in Newark, New Jersey. Taking social incivilities into consideration, the current research contributes to the literature with a qualitative comparison of safety perception between residents and commuters on the same university campus. Findings help to focus on where to manage public behavior to modify the perceived safety.

\section{Literature Review}

Personal safety is associated with physical and social contexts as well as personal factors $[10,11]$. Perceived personal safety is related to feeling free from the fear that may arise from any harm [11]. According to Warr [12], "When individuals face an ostensibly dangerous environment, they may naturally experience fear for their own personal safety." The differential features of social environments in urban settings have been largely probed to understand the potential influence on the fear [13-16]. For example, Taylor [16] observed that a socio-physical environment does not influence every individual to the same extent, and 
different individuals report varying levels of fear in the same area. However, the research on the link between the social environment and safety concerns has been mostly quantitative [16], and more studies are needed to unfold the mechanism and processes in this relationship.

In the literature on campus safety, scholars previously studied perceived safety of women on specific crimes $[1,3,4,6,9]$, or gender difference in perceiving danger $[2,5,7]$. Since crime occurs in different settings with distinct social and physical characteristics, fear arising from crime, similarly, varies by behavior in public places. Most qualitative research on the safety of university campuses has not captured the resident-commuter difference in the impact of social incivilities on safety perception. To contribute to this field of research on the relationship of social environment with the perception of safety, this current study is basically focused on three ecological themes that emerged from the qualitative data and the literature review. The recurring themes across interviews with college students were associated with the street homeless people, street vendors, beggars, and people congregating at street corners in the relevant literature.

According to Wilson and Kelling 1982, when a community experiences disorder in public places, the residents feel unsafe. Later scholars defined social disorder as a boorish or threatening behavior that disturbs life in, especially, urban areas [17]. The disorderly social behaviors might be in the forms of, among many others, rowdy teenagers congregating around street corners, drinking in public, or panhandling. Social disorder is mainly about the situations involving antisocial behavior in the neighborhood $[15,18]$. Arguably, social disorder influence how safe an in individual feels in an urban setting. Also known as incivilities thesis [19], "broken windows" theory posits that unchecked physical disorder and untended disorderly social behavior cause residents of an area to be fearful. Under the influence of fear, people's attachment to their neighborhood weakens. According to [20], the incivilities underlie signs of crime or its related clues. Thus, the presence of incivilities might raise an individual's fear directly [21-23] or indirectly $[13,15,21,24]$. In other words, the perception of high levels of social disorder in a particular place is related to higher levels of fear of crime [18,21,25-29]. However, some argued that the perception of environment in a neighborhood may vary from one person to another based on their familiarity with the environment $[16,19,30]$. The perception of safety about the same locality may also differ between residents and nonresidents. Empirical research on campus safety mostly compared the perception and fear by gender. Fisher and May [2] suggested that women significantly reported more that groups congregating was the fear-provoking cues to them. But, Patton and Gregory [8] reported that the gender difference in perception of campus safety was not significant in their sample of 11,161 college students.
Drawing on this literature review, the current study examines

a) Which specific social incivilities shape a student's perceived safety that in turn causes safety concern on campus;

b) How these factors influence the perception, and

c) Whether the students` perceptions vary by the state of residency on or off the campus.

\section{Methodology}

\section{Procedures}

The current research was based on the in-depth interviews with a sample of 28 Rutgers University students who continued their college education on campus in Newark, New Jersey. The research team consisted of graduate students to collect the data for this study during the fall semester in 2013. Doctoral students of the Rutgers School of Criminal Justice program conducted interviews with undergraduate students of the Rutgers Newark campus. Researchers used a semi structured interview guide to ensure a standard in the data collection. Before deciding what questions to ask participants, the researchers met with a ranked police officer from Rutgers University Police Department to learn more about safety related issues on the campus. Then, the interview guide was prepared with the contribution of researchers in order to collect data by each researcher`s area of interest. The in-depth interviews were semi structured, with open-ended questions that enabled considerable probing. Research involved 28 interviews in total.

Sampling strategy aimed at stratified purposive sampling by the different departments of the Rutgers University in Newark, but it ended up being somewhat overloaded with criminal justice students. As the members of the research team were graduate students in the criminal justice program, the college students were reached at their classrooms by one researcher from our research team. Those who were willing to participate in provided the research representative with their email addresses. Then, the researcher who invited the student to participate in our research assigned a volunteer to each of other researchers. However, not every student who provided his or her email address responded to the invitation emails from the members of researcher's team, thus some of them did not participate in interviews.

\section{Data Analysis}

With respect to sample characteristics, the subjects ranged in age from 18 to 34 , with the mean age 22.14. They were from different races, of which 5 were African American, 2 HaitianAmerican, 6 multiracial, 5 Hispanic, 3 South Asian, and 7 White. The sample was balanced in gender, as 14 participants were male, 13 female, and 1 gender queer. The sample included 22 U.S. citizens and 6 international students. The subjects were not in the same year of their college education; 9 were first-year students, 6 two-year students, 2 two-and-a-half year students, 
6 three-year students, and 5 four-year students. Their field of education also varied. The research team interviewed students from Criminal Justice (11), Psychology (5), Political Science (3), Accounting (2), English (2), Actuarial Science (1), Geology (1), Medical Imaging (1), Journalism (1), and Social Work (1) departments.

The sample was also balanced with respect to participants state of residency on campus. The current study is mainly interested in the relationship of environmental factors with safety perception, and the basic assumption is that the perception of safety may change by the state of residency, particularly between residents and nonresidents of campus. Accordingly, the sample included 11 participants who are living on campus, 2 near campus, and 15 off campus. For the ease of analysis, those living near campus were included into the group of the resident students.

The students who were commuters or campus residents in this study were comparable on a number of demographic characteristics. The resident participants were younger (mean age $=20.85$ years) than their commuter counterparts (mean age $=23.26$ years). This difference was relatively insignificant. Among commuters 8 students were male, 7 were female. In the residents' group, 6 participants were male, 6 female and 1 gender queer. The representativeness of a sample of students on the Rutgers Newark campus could not be determined conclusively because the parameters of the population are unknown. Nevertheless, we took steps to make our sample more representative. For example, we initiated a selection process from 57 students who volunteered before the first phase of interviews. Participants were contacted after screening their race, gender, residence, and years in the university to balance the sample on these parameters. The criterion for selecting race, gender, and years in college was based on the previous studies in this field of inquiry.

After the selection of the sample, the semi-structured interviews were conducted informally. The interviews were also recorded in the form of digital audio files with an informed consent, and then transcribed verbatim. The researchers were close to the participants in age, and the interviews had a conversational flow in a way to let them use their own concepts and terminology. Interview participants were granted a ten-dollar Starbucks gift card for their participation in the research. The result was a relaxed atmosphere that appeared to enhance students' confidence. Interviews typically lasted one hour to one and a half hours. The general impression was that the interviewees thought seriously about the questions and responded truthfully. The students took part in the research voluntarily. To preserve their anonymity, respondents are identified by pseudonym names throughout this article. The results of this research are presented in a qualitative form.

\section{Study Setting}

Rutgers Newark Campus is located in Newark City that is a distressed urban city. Newark is the largest city in New Jersey. According to 2010 United States Census, its population is about 280,000 people [31]. Poverty is a consistent problem in the city with one-third of population being impoverished [32]. Crime is also an important issue of the city. The Rutgers Newark Campus is not physically isolated from the rest of Newark City. There are over 2,000 students living on campus between Rutgers University - Newark, as well as Rutgers Biomedical and Health Sciences. Traffic can flow through the campus, and it is an open space that any person can use.

\section{Findings}

During the interviews, two questions were specifically about the perception of safety of the interviewees. One question measured the environmental factors that could shape individual`s safety perception. Interviewers asked respondents "whether there are particular people, places or things in the environment that make them feel more (or less) safe at times." Another question was "whether they have been worried about their safety", to which responses included the expressions of thoughts about the environment. With respect to social disorder, the most frequent mentions were about homeless people, vendors, beggars, and a group of people standing on the corner. College students reported their ideas about disorder and safety concerns in 19 interviews (about 64\%). Table 1 illustrates the frequencies of the mentioned cues by the residency status and gender. The following part is a qualitative analysis that is useful to understand the nature of the relationship between perception of environment and safety.

Table 1: Mention frequency by categories of residency and gender.

\begin{tabular}{|c|c|c|c|c|}
\hline Incivilities & Residents & Commuters & Male & Female \\
\hline Homeless & 5 & 5 & 4 & 7 \\
\hline $\begin{array}{c}\text { Street } \\
\text { vendor }\end{array}$ & 2 & 2 & 2 & 2 \\
\hline Beggar & 2 & 7 & 3 & 4 \\
\hline $\begin{array}{c}\text { Congregating } \\
\text { on streets }\end{array}$ & 2 & 5 & 3 & 4 \\
\hline
\end{tabular}

\section{Social Disorder}

The college students used various words about boorish behavior of other people, which causes a feeling of danger. They talked about homeless people, beggars, vendors, candy sellers or youth congregating at a street corner and yelling passersby. Participants qualified homeless people differently. They were defined as "obnoxious", "inconvenient", "invading your space", "junkies", and "unstable."

\section{Homeless}

In this study, the views on homeless people as a safety concern were more of a resident-commuter similarity than difference. In 
mentioning homelessness, female respondents outnumbered male students by seven to four. For some, homeless people are not harmful, though they elicit discomfort for the students in an environment. As an example of this similarity, Amina, (female resident) and Zofia (female commuter) stated that homeless people are not dangerous. Amina, a junior student in economics program, noted there are homeless people on campus, and they give a feeling of discomfort rather than insecurity. The discomfort comes from their cursing or yelling at people.

"...even in front of my dorm sometimes there are like people who might make your feel uncomfortable like homeless people and I don't want to offend them in any way. ..., [one of them] was obviously homeless and he was constantly cursing at people because they weren't giving him money and all that. That's like I wouldn't say I felt insecure because he can't really do anything to me right there. It just makes me uncomfortable sometimes."

What is more for Zofia-a sophomore student of criminal justice program- is that their behaviors are unpredictable, as she witnessed a homeless person happened to walk into classrooms and tried to snatch food from somebody:

"I had a situation that there are homeless people. I am not saying that there is something wrong with them, but there was a situation once I remember during the summer, homeless person literally walked in to the classroom and he was trying to snatch food from somebody. I feel like this is kind of crossing the line, you know, yea you are within the campus area. It is public, but I would not want him to come into the building. I am not saying that they will do anything to me, but it just makes me feel uncomfortable. It's not that it is just you know like people when they're hungry or scared or whatever, they might do different things, you know so."

For the harmfulness of homeless people, there was a variation of thoughts among participants who see homeless as not dangerous. A female resident and freshman student, Chante noted that "they're not harming anyone but in a way it's kinda like why are these people on here." Besides their yelling and cursing, homeless people ask students for money. One participant mentioned this when asked whether there is anything good or bad living on campus. A male campus resident and junior in Criminal Justice program, Brad remarked, "bad! I would say there is always like you know homeless people asking you for money. It's just inconvenient. It doesn't make me feel good about where I am when that happens."

The presence of homeless people is also a reason for avoiding a public place. Though most homeless people are not dangerous for her, Christian, a male commuter and freshman in Accounting program, said, "Especially the business school, right here, it's just a building located there and it's near places that I wouldn't want to hang out. You see homeless people around." For others, it was not the case that homeless people are not harmful. Around the campus, there are people asking students for money, introducing himself as a homeless veteran. When the students do not oblige the homeless people's request for money, these people begin to curse at the students. Sometimes they can even threat the people who are present in the immediate environment. A male resident and freshmen student in English department, Waverly sees them as scaring and unstable. A female commuter and junior in Criminal Justice program, Lauren sums this up in her narrative about a frightening situation of hers and her friend:

"... I was outside with my friend and there was this guy who approached us asking for money - not money food. But he was like, "I'm a war veteran." ... "And my wife left me so now I'm homeless and I don't have money to eat so I'm just trying to get some food." And we were like, "I have a card, like a debit card. There's a truck there. I can get you food." And he was like, "No, I just need the cash." Blah blah blah! So then my friend was like, "Here are two dollars." And a lot of people don't carry cash around anymore like ... I usually just have the debit card or the credit card because that's like, if I need it, I'll use it in the store or something. Um, and when we gave him the money, he actually was like: "This is $S$-." The S-word. And he's like, "I can't buy nothing with this.". We can get a hot dog for like a dollar at that truck... But we were trying to tell him like, "there's a truck there that would give you food for \$2." And he like, screaming, kind of getting closer to my friend and cursing or saying how we're inconsiderate. He was saying, "You're just generalizing me. I'm not gonna go get drugs. I'm gonna go get food." I'm like yea but there's a truck right there where you can go get food at, right there. he was like I cant get anything for $\$ 2$. He just left screaming. He was getting closer to my friend so my friend was like, "You do that again, I'm gonna punch you in the face. Get away from me." And it was just like, okay, at that point, something's about to happen right now and I don't want to be a part of it. When he left and started like, screaming about whatever he was screaming about He got away and left. It was a guy. We probably wouldn't have told him anything."

Based on her own experience with a homeless on campus, Tamara, a female commuter and senior student majoring in Social Work, was not as comfortable as other participants in arguing that a homeless can`t do anything wrong to a person. Furthermore, she avoided places where homeless people were walking around because they are "approaching you and invading your space".

"... there is homeless people always walking around. They always approaching you, invading your space.... I'm in Subway [a restaurant on campus] and this guy he walks up to me. He is not saying anything, but he knows (mumbles), I'm like okay he is just staring at me. And so the guy, the store owner goes (acts out like a move away action), he is yelling at him get out. But I mean frequent homeless people walking in and out of Subway and stuff like that. So it kind of makes you nervous, cause you don't know what peoples intentions are nowadays, so I love my Subway but I try 
to just get it and go. I will just grab a sandwich and eat it in my class, I feel much safer eating it in my class.... in Smith Hall, last semester specially in the summer time. I took a summer course and this lady, I won't say she is homeless but she had a lot of baggage with her in the building, she kept going around asking people for money and I'm like okay, what is she doing here. Everyone pretty much ignored here, then she started lashing out, just cursing and stuff. But there was no security on site, like who knows she could have attacked somebody been, ran out the building and went her way. So it could, definitely some safety issues, you know we need to look into on campus..."

In this sample of college students, the most common form of social incivility reported by students was the homeless people in and around the campus. Homeless people beg for money, and they do this not for their needs but just for more money. In our sample, not every respondent had an experience with a homeless person, but the discomfort that homeless people cause in general was spoken about among the students.

\section{Street Vendors}

Four participants similarly reported that people who sell items on the streets make them uncomfortable in the area. The wording also varied by respondent, which included "vendors", "people trying to sell you stuff on street", and "candy sellers". While Quinn (a male resident and sophomore in Business program) qualified it as an "annoyance", Lauren (commuter) views what street vendors are doing as harassment. Tough she did not witness a robbery case directly, Yardley (a female resident and junior in Criminal Justice program) linked her experience with a candy seller to an armed robbery incident when she told, "I saw this guy with a little girl, and they were selling candy on campus. And then, like, weeks later they sent out an email saying that it was a strong-arm robbery where the guy who was selling candy forced a guy to give money, like, a donation."

The street vendors bother some students too, and how these people make the students feel was reflected in Quinn`s description of places where he avoids:

“.. there's places that I just don't go just because I don't really have to go there... it's mainly because there's always like vendors there and they're always trying to hustle you. They're just like "yeah, "I've got a hat for two bucks man, two bucks!": And that's the main reason. It's not safety, it's just more of a, a hassle or annoyance more than anything else... they-it's more of an annoyance than anything else. It's just like "I don't wanna buy-like I'm a dude, why would I wanna buy your purses?".. "Stop haggling me for money for your addiction or whatever it is that you might have."... "I feel bad for you, but it's just like I don't wanna be the one that's helping you with it." I was just like "I'm sorry if it makes you feel like an a-hole for ignoring you, but that's how it is... Yeah. I try to like, if I have like, some pocket change from like a previous transaction, I'll be like "alright, this is all the change I have.". And like I won't give him like my dollar bills, but I'll give him like coins. I have, like I've maybe some karma or some.. (laughs)."

In residential-versus-commuter comparison, two respondents were resident, and two commuters also mentioned vendors. This balance was also observed in gender as two students were male and two female.

\section{Beggars}

Six participants in the sample, which included three residents and three commuters, mentioned that some people asked them for money. But, five students were female and one male. They used the words "sketchy people", "beggar", or "panhandler" to describe these people. With respect to the feelings that their behaviors caused in students, the participants stated that those behaviors heightened students' concerns about safety. For Shaun, "it is like a turn-off. It sort of deters me from, from even, sometimes umm, walkin' throughout the campus and just, you know", which should be policed too.

\section{People Congregating at Street Corners}

Seven subjects in our research had reports about this construct, which was qualified in such various terms as "a group of people standing on the corner", "a crowd of people", "gang members around corner stores", or "people congregating in certain blocks". Our respondents expressed their feelings as "raising awareness", "having a feeling of what's going on", or "it's like I can't walk this area by myself" as seen in Heather's accounts, who was a female commuter and freshman in Criminal Justice program:

"...So I walked over and there was like a group of people standing on the corner. Obviously they were African Americans. They were males, and uh, you know, I'm walking and they were like, "Yeah white meat," you know, like, yeah and I was, "Nope." And I turned around. I went back. I was like, "I'm not doing this because I know Newark is not the safest of places." So it's like I can't - I can't walk in that area by myself" Commuters were different than residents on this construct as five out of seven participants who mentioned it were commuters. Four female and three male students talked about this social incivility.

\section{Discussion and Conclusion}

This study examined the cues in the social environment that provoke safety concerns of the students of a college campus. The recurring words used by participants were associated with four main concepts in the relevant literature; homeless people, street vendors, beggars, congregations at street corner. Few studies addressed the influence of environmental cues on perceived safety of campus, and they compared gender difference in this perception. To contribute to the body of research on campus safety, the current study compared whether and how commuters 
and residents perceive the same environment differently on their safety by taking gender difference into consideration across the themes. Such an analysis is important in three respects. To improve quality of life on campus, practically important is to know what specific social features the students point out in the environment as unsafe. Besides, familiarity with campus is related to time spent on site, and the perception may vary by residential status, regardless of gender. Further, prior studies did not comprehensively address all the social cues in one setting as the current research does. With all those aspects in mind, the accounts of 13 campus residents and 15 commuter students were examined. The sample was also balanced in gender with 14 female, 13 male and 1 genders queer.

Beggars and people congregating at street corners were more frequently expressed in the commuter group. In comparing perception by gender, homeless people were more frequently defined as fear-provoking by female participants. With respect to themes under the category of social disorder, the presence of homeless people was reported as a reason for avoiding a public place. There was not an observable contrast between residents and commuters in their views about homeless people, though more female students talked about homelessness. Some participants viewed homeless people as dangerous, while others did not do so. These safety concerns were observed in other studies as well [33-35]. Although students reported their views differently on homeless people, some evaluated the physical closeness of an aggressive homeless as harmless but uncomfortable in various respects.

There is a scant attention in the literature on the safety aspect of vending legally on streets for people of the area, and he views about street vendors are mixed. For some, street-sellers were qualified as "eyes on the street" for natural surveillance and safety of streets [36], and they were also associated with safety risks for others [37]. The latter was distinctly observed in our sample of college students, and some participants further stated them to be a hustle or annoyance when street vendors importunely insisted them to buy what they were selling. It also turned out that importunely asking for money occurred in three different forms; homeless begging for money, beggars/panhandlers, and street vendors. Though the students distinguished the themes, future research should probe whether and how the students view those three groups differently.

Commuter respondents more frequently mentioned the presence of beggars and panhandlers around to be a concern for safety in accord with the previous literature [38,39]. The last aspect of social disorder was congregations on streets. People who congregate at street corners may be perceived offensive towards passers bys with even their presence, and the current study substantiates findings from earlier research $[14,18,22]$.

Thinking back the familiarity of an occupant with the area, in the relevant literature is also the argument that knowledge of an area might have a protective effect on perception when people know each other and the area around the clock [39-41]. Our interviews did not include specific questions to draw students' attention on groups loitering such as "how do you feel when you see a group loitering in and around the campus?" However, the observation that commuters more frequently matched this theme with their safety lends partial support to the protective effect of familiarity with the area on how the occupants perceive it, and thus the residents might not have mentioned them to the same extent. To explore further, future research should ask the subjects how they perceive when a group of people are congregating and loitering around the street corners.

The research had limitations as well. As eluded to above, participants were predominantly from criminal justice program in our interviews, though the sample included students from ten different programs. In addition, specific questions for day-timeversus-night-time comparison were not in our interviews. Given that the questions in the interview were open-ended for the relationship between the social incivilities and safety concerns, and that they did not specifically evoke any natural, social or built object or behavior on campus; these patterns suggest that the social features in the environment had differential influences on the perception of college students not only by gender but also by their familiarity with the campus.

It is a costly and difficult task to ensure safety of every single individual in the open-campus universities since people from without the university community may flow into the campuses. On the other hand, there is no doubt that feeling safe increases the quality of life for the members of a community, including the college students. For the safety and comfort of college students, other institutions with similar ecological features might also consider the findings of this study about the potential cues in the environment while future research should probe more the potential influence of anonymity on safety concerns in educational facilities.

\section{References}

1. Day K (1994) Conceptualizing women's fear of sexual assault on campus: A review of causes and recommendations for change. Environment and Behavior 26(6): 742-765.

2. Fisher BS, May D (2009) College Students' Crime-Related Fears on Campus Are Fear-Provoking Cues Gendered?. Journal of Contemporary Criminal Justice 25(3): 300-321.

3. Hilinski CM (2009) Fear of crime among college students: A test of the shadow of sexual assault hypothesis. American Journal of Criminal Justice 34(1-2): 84-102.

4. Kelly BT, Torres A (2006) Campus safety: Perceptions and experiences of women students. Journal of College Student Development 47(1): 2036.

5. Kirk NL (1988) Factors affecting perceptions of safety in a campus environment. EDRA: Environmental Design Research Association 19: 215-221.

6. McConnell EH (1997) Fear of crime on campus: A study of a Southern university. Journal of Security Administration 20(2): 22-46. 
7. Nasar JL, Jones KM (1997) Landscapes of fear and stress. Environment and behavior 29(3): 291-323.

8. Patton RC, Gregory DE (2014) Perceptions of safety by on-campus location, rurality, and type of security/police force: The case of the community college. Journal of college student development 55(5): 451-460.

9. Wilcox P, Jordan CE, Pritchard AJ (2007) A multidimensional examination of campus safety: Victimization, perceptions of danger, worry about crime, and precautionary behavior among college women in the post-Clery era. Crime and Delinquency 53(2): 219-254.

10. Blöbaum A, Hunecke M (2005) Perceived danger in urban public space: The impacts of physical features and personal factors. Environment and Behavior 37(4): 465-486.

11. Waters J, Neale RH, Hutson S, Mears K (2004) Personal safety on university campuses- defining personal safety using the Delphi method. In: Khosrowshahi F (Eds.), 20 ${ }^{\text {th }}$ Annual ARCOM Conference, University of Glamorgan, Llantwit Road, Pontypridd, CF37 1DL, UK, 1 411-418.

12. Warr M (2000) Fear of crime in the United States: Avenues for research and policy. Criminal justice 4(4): 451-489.

13. Ferraro, Kenneth F (1995) Fear of crime: Interpreting victimization risk. Albany: State University of New York Press, USA.

14. Garofalo J, Laub J (1978) The fear of crime: Broadening our perspective. Victimology 3: 242-253.

15. LaGrange RL, Ferraro KF, Supancic M (1992) Perceived risk and fear of crime: Role of social and physical incivilities. Journal of Research in Crime and Delinquency (29): 31-334.

16. Taylor RB (2001) Breaking Away from Broken Windows: Baltimore Evidence and Implications for the Nationwide Fight Against Crime, Grime, Fear and Decline, Westview Press, New York, USA.

17. Kelling G, Coles CM (1996) Fixing Broken Windows: Restoring and Reducing Crime in Our Communities. Free Press, New York, USA.

18. Skogan W (1990) Disorder and decline. Free Press, New York, USA.

19. Harcourt BE (2001) Illusion of Disorder. The False Promise of Broken Windows Policing. Cambridge, USA.

20. Skogan WG, Maxfield MG (1981) Coping With Crime: Individual and Neighborhood Reactions. Beverly Hills, CA: Sage, USA.

21. Covington J, Taylor RB (1991) Fear of crime in urban residential neighborhoods: Implications of between-and within-neighborhood sources for current models. Sociological Quarterly 32: 231-249.

22. Perkins DD, Taylor RB (1996) Ecological Assessments of Community Disorder: Their Relationship to Fear of Crime and Theoretical Implications. American Journal of Community Psychology 24: 63-107.

23. Robinson JB, Lawton BA, Taylor RB, Perkins D (2003) Multilevel longitudinal impacts of incivilities: Fear of crime, expected safety, and block satisfaction. Journal of Quantitative Criminology 19: 237-274.
24. Rountree PW, Land KC (1996) Perceived risk versus fear of crime: Empirical evidence of conceptually distinct reactions in survey data. Social forces 74(1): 1353-1376.

25. Bursik RJ, HG Grasmick (1993) Neighborhoods and crime: the dimensions of effective community control. Lexington Books, New York, USA.

26. Lewis DA, Salem G (1986) Fear of crime: Incivility and the Production of a Social Problem., NJ: Transaction Books, New Brunswick, USA.

27. Markowitz FE, PE Bellair, AE Liska, J Liu (2001) Extending social disorganization theory: modeling the relationships between cohesion, disorder, and fear. Criminology 39: 293.

28. McGarrell EF, Giacomazzi AL, Thurman QC (1997) Neighborhood Disorder, Integration, and the Fear of Crime. Justice Quarterly 14(3): 479-500.

29. Taylor RB, Hale M (1986) Testing alternative models of fear of crime. Journal of Criminal Law and Criminology 77: 151-189.

30. Martin-Storey A, Crosnoe R (2014) Perceived Neighborhood Safety and Adolescent School Functioning. Applied developmental science 18(2): 61-75.

31. US Bureau of the Census (2015) Population estimates: Newark, New Jersey, US.

32. Joshua (2017) “Report: Newarkers Among New Jersey’s Poorest”. New York, USA.

33. Gearin E, Kahle C (2006) Teen and adult perceptions of urban green space Los Angeles. Children Youth and Environments 16(1): 25-48.

34. Krajewska-Kułak E, Kułak-Bejda A, Łukaszuk C, Guzowski A, Cybulski M, et al. (2016) Attitudes of medical students towards homeless people. Probl Hig Epidemiol 97(4): 377-381.

35. Perkins DD, Wandersman A, Rich RC, Taylor RB (1993) The physical environment of street crime: Defensible space, territoriality and incivilities. Journal of Environmental Psychology 13(1): 29-49.

36. Jacobs J (1961) The death and life of great American cities. Vintage Books, New York, USA.

37. Bromley R (2000) Street vending and public policy: a global review. International Journal of Sociology and Social Policy 20(1/2): $1-28$.

38. Skogan W (1986) Fear of crime and neighborhood change. Crime and justice 8: 203-229.

39. Wilson James Q, George L, Kelling (1982) Broken windows: The police and neighborhood safety. Atlantic Monthly p. 29-38.

40. Innes M, Jones V (2006) Neighbourhood Security and Urban Change: Risk. Resilience and Recovery, Report from Joseph Rown Tree Foundation, UK

41. Pain R (1997) Old age'and ageism in urban research: the case of fear of crime. International Journal of Urban and Regional Research 21(1): 117-128. 
Your next submission with Juniper Publishers will reach you the below assets

- Quality Editorial service

- Swift Peer Review

- Reprints availability

- E-prints Service

- Manuscript Podcast for convenient understanding

- Global attainment for your research

- Manuscript accessibility in different formats

( Pdf, E-pub, Full Text, Audio)

- Unceasing customer service

Track the below URL for one-step submission https://juniperpublishers.com/online-submission. 